\title{
NUCLEAR ENERGY AND ITS IMPORTANCE IN ROMANIA'S ENERGY IDENTITY
}

\author{
Ms. Luminița-Stela PETROVICI ${ }^{453}$
}

\begin{abstract}
Uncertainties caused by energy dependencies affect the energy security of the states in the region, and implicitly their national security. Romania is in a relatively unique position between the states in the region and those in the EU, given the energy potential. In the next period, taking into account the commitments assumed at the European level, but also the need to revive the National Energy System, Romania will define its energy identity. In this equation, a topic of interest at the moment is the question of nuclear energy, and whether the current historical logic still brings relevance to this way of producing energy, considering also the appropriate security implications. This paper deals with the issue first in terms of defining the place of the nuclear sector in the energy identity of Romania, then pointing out some aspects related to security. Finally, the conclusions are presented in the form of development perspectives.
\end{abstract}

Keywords: Romania; EU; nuclear energy; energy identity; security.

The energy sector contributes substantially to Romania's development, with a direct impact on the economy, the environment, and the daily life of its citizens ${ }^{454}$. In line with current EU carbon footprint reduction requirements, Romania's energy sector seeks to become even more economically important, more technologically advanced, and less polluting. Overall, it can be said, in other words, that Romania is transitioning to a better energy efficiency figure.

Romania's energy policy aims at harmonizing with the European policies assumed for 2030, being oriented on three main directions: competitiveness, sustainable development, and last but not least security ${ }^{455}$. In light of these three pillars, Romania's Energy Strategy 2016-2030, but also the one planned for 20202030, with 2050 perspective, identifies the need to transform the energy system through investments in priority sectors and develop the necessary infrastructure, which is the substance of this national strategic project. Assumed in this project as an important part is the sustainable development in the field of nuclear energy.

In the context of European energy and climate change policies, in force since 2007, energy policy aims to take into account the energy and environmental objectives adopted by the European Council for 2030, as well as the initiatives

\footnotetext{
${ }^{453}$ Ms. Luminiţa Stela Petrovici is Communication Officer in the field of renewable energy.

${ }^{454}$ Ministerul Economiei, Energiei și Mediului de Afaceri, Strategia energetică a României 2020-2030, cu perspectiva anului 2050 (proiect), http://www.mmediu.ro/app/webroot/uploads/files/Strategia\% 20Energetica\% 20a\%20Romaniei_aug\%202020.pdf, p.4.

${ }^{455}$ Ibidem, pp.8, 21-25.
} 
launched by the European Commission to promote the Clean Energy Package. Nuclear energy, as a source of energy with a small footprint in terms of greenhouse gas emissions, in this case, carbon, also has a significant share of total Romanian electricity production - about $18 \%$, is one of the main routes for Romania to it also achieves the commitments made at European level, but also the consolidation of energy independence - which, fundamentally, contributes to increasing the national energy identity. National nuclear energy is also supported by internal resources and infrastructure for the entire nuclear circuit - from fuel to moderators, to operating infrastructure, to the generation and regeneration of material and human resources, to experience in the field of more than three decades; practically, Romania has a high degree of independence in the field of nuclear energy ${ }^{456}$.

Romania has all the ingredients to become one of the countries in the world with a strong nuclear profile in the country's energy portfolio, but this brings with it several challenges, including, last but not least, the issue of nuclear security, in the sense including nuclear safety.

\section{THE CURRENT STATE AND NEED OF THE NUCLEAR ENERGY SECTOR IN ROMANIA}

In an attempt to develop a national energy identity that is characterized, first and foremost, by attributes such as security, efficiency, and independence, Romania has encouraged the development of the energy sector in a formula that brings together energy resources based on fossil fuels and renewable resources, green. In 2017, the composition of this mix had as its first resource used, from a quantitative point of view, crude oil - with a percentage of $32.6 \%$ of total energy, natural gas - with $27 \%$ of the total, renewable and low polluting energies, including energy nuclear $-15.2 \%$, coal - with a percentage of $15 \%$, and, also, $8.7 \%$ percent from imported petroleum products ${ }^{457}$. Of the total resources used, the ratio between domestic and imported products is 2:1. The use of all available resources, an essential beneficial thing, brings with it the obligation of responsibility for damage caused to the environment, especially in the European context, but also in terms of quality of life, in terms of citizens' health, in the narrowest form of this responsibility, until the conservation of non-renewable resources and the environment for future generations, the preservation of the environment as unaltered as possible and the maximum efficient use of green and/or renewable energies, in the most comprehensive sense.

\footnotetext{
456 Ibidem, p. 17.

${ }^{457}$ National Institute of Statistics, citat în Strategia energetică a României 2020-2030, cu perspectiva anului 2050, pp. 28-29.
} 


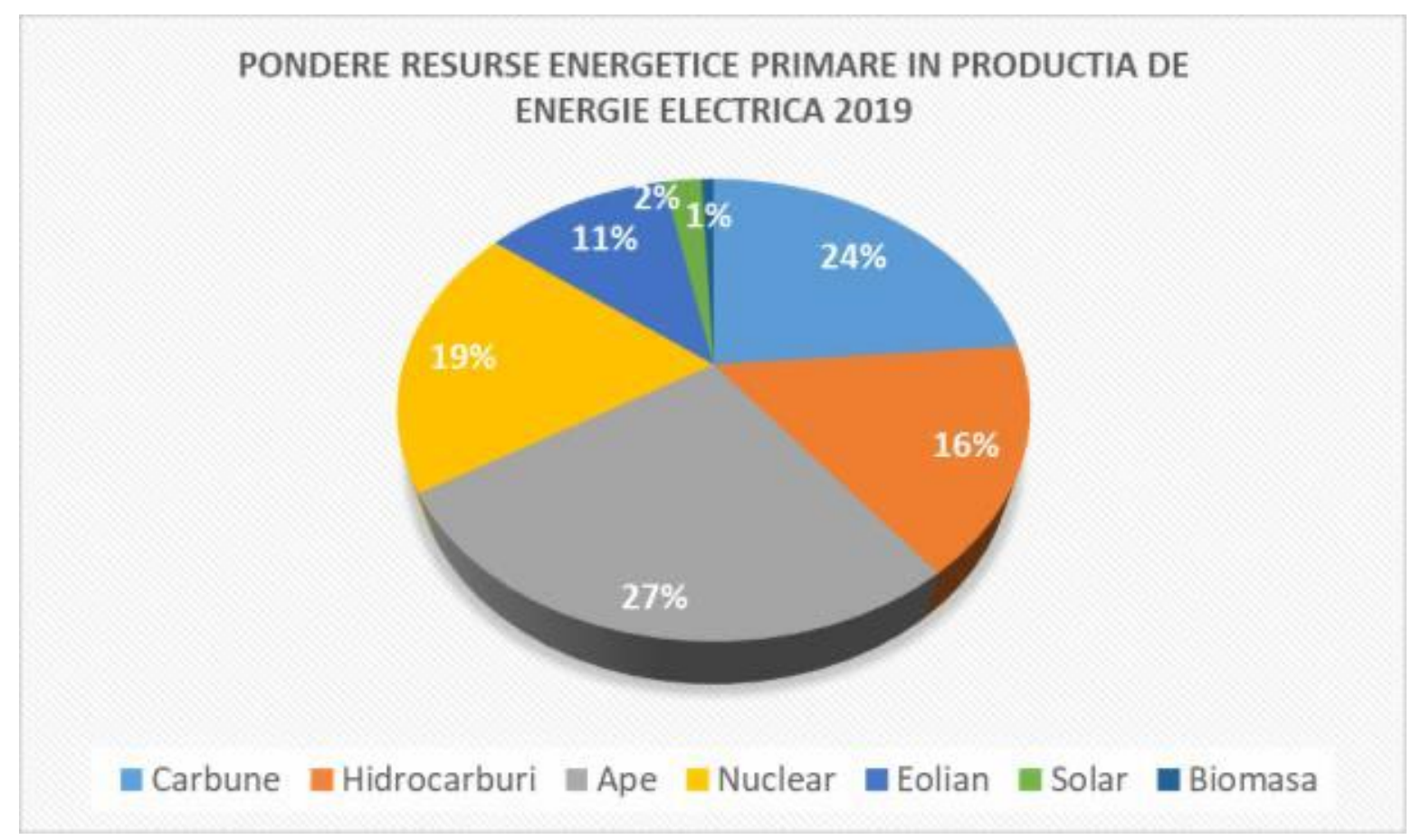

Of this national energy total, a significant part is capitalized in the form of electricity, necessary to cover electricity consumption at the national level, but also for energy exports. Of the total electricity produced, $40 \%$ comes from burning fossil fuels - especially coal (24\%), followed by hydrocarbons (16\%). Most nationally produced electricity, therefore, comes from low or no polluting sources, including hydropower accounting for $27 \%$ of total production, nuclear energy $19 \%$, wind energy $11 \%$, and solar energy (2\%), and biomass (1\%) are underrepresented ${ }^{458}$.

From the point of view of the generation infrastructure, a significant part of it is older than 30 years, which leads to the need to review the processes and reevaluate the number of operating hours remaining until the expiration of the technical duration of the operation. Repairs and maintenance are activities that currently require a higher frequency of decommissioning of the various components of electricity production and distribution. Moreover, some of the older energy groups are already in conservation. Although this state of affairs is not necessarily gratifying, at first glance, analysis beyond the surface shows that the category of these older groups includes those components of the National Energy System (SEN) that use non-renewable energy resources, in addition to those in the field of hydropower and nuclear energy. It is therefore gratifying that green, renewable technologies, to a significant extent, are relatively new, on the one hand, and on the other, the current state of hydropower and nuclear energy allows future investments to target these carbon footprint sectors. And negative effects on the environment and reduced human life. Moreover, Romania plans to

\footnotetext{
${ }^{458}$ Strategia energetică a României 2020-2030, cu perspectiva anului 2050, p.38.
} 
increase the percentages of renewable or low-polluting energy from the total, following the responsibilities assumed at the European and national level, both to increase energy efficiency and to reduce greenhouse gas emissions ${ }^{459}$.

Given the objectives of efficiency and reduction of environmental pollution, it becomes clear that, in the long run, the development of new energy production capacity (even electricity) based on fossil fuels will be counterbalanced by the associated costs, possible additional payments incubated by the use of polluting technologies, the need to build a strategic reserve for SEN safety, the performance of the system and the need to cover energy demand in the internal market. In defining the energy identity of SEN, renewable/green energies will therefore occupy an increasingly important place. However, the preservation of a compositional diversity allows maintaining the resilience of SEN, especially to overcome moments of extreme stress caused by adverse weather for hydropower, wind, or solar energy - the absence of wind, high degree of cloud cover, increasingly extreme temperatures more common, lower water levels. As a result, ,SEN is subject to vulnerabilities in ensuring full coverage of energy demand for both domestic consumption and exports if neighboring states face the same situation" $" 460$.

In such conditions, it is necessary to have production capacities independent of environmental factors, which is why Romania has decided not only to maintain its option to use nuclear energy but even to develop this capacity, so that it can ensure a percentage higher of the total electricity consumed, coupled with the disconnection of several non-green production facilities. At present, in addition to units 1 and 2, both using Canadian technology and CANDU 6, second-generation reactors $^{461}$, it is desired to develop two more production units, which is why it is estimated that the percentage covered by electricity produced at Cernavoda will rise to $28 \%$ of the total, for the year $2035^{462}$.

In 2019, in September, the Romanian state signed a Memorandum of Understanding with the government in Washington, to strengthen the bilateral relationship in the area of civilian capability development (essentially, a treaty for the development of cooperation in the field of nuclear energy). Thus, Romania seeks to develop its experience in the field of nuclear energy, an area that ,is deeply rooted in mutual national security and strategic interests and supports our energy security objectives" ${ }^{\$ 63}$. This memorandum was further used in October

\footnotetext{
${ }^{459}$ Planul Național Integrat în domeniul Energiei și Schimbărilor Climatice 2021-2030, April 2020, pp. 45-60.

${ }^{460}$ Strategia energetică a României 2020-2030, cu perspectiva anului 2050, p.38.

${ }^{461}$ Nuclearelectrica. CANDU 6 type nuclear reactors, installed in units 1 and 2, with $700 \mathrm{MW}$ of installed capacity, operate with natural uranium, and heavy water as moderator and coolant - CANDU (Canadian Deuterium Uranium). The nuclear fuel plant in Pitești (located more precisely in Mioveni, AG) provides the nuclear fuel necessary for the operation of Cernavoda NPP, the uranium ore coming from the mines from Crucea, SV, operated by the National Uranium Company.

${ }^{462}$ Strategia energetică a României 2020-2030, cu perspectiva anului 2050, p.38.

${ }^{463}$ US Department of State, U.S. and Romania Sign Nuclear Cooperation Memorandum of Understanding, 25 september 2019.
} 
2020, following the announcement of an initial agreement on cooperation for the development of modernization and expansion projects at the Cernavoda Nuclear Power Plant, which aims, among other things, to upgrade unit 1, but especially the development of units 3 , respectively $4^{464}$. The development of the nuclear energy sector is therefore closely linked to the ideas of energy security and independence, fundamental issues for national security, and the prosperity of a state. The possibility of achieving energy production that, on the one hand, ensures the need for domestic consumption and not only, and on the other hand, is generated by non- or low-polluting technologies, in the context of current climate change and the responsibilities assumed at European level on reducing the carbon footprint, are sufficient reasons to generate traction to create an energy identity in which nuclear energy maintains a significant place.

\section{SECURITY AND THE NUCLEAR SECTOR - BENEFITS AND RESPONSIBILITIES}

The presence of the nuclear sector in the Romanian energy landscape brings to the fore the issue of security, from two perspectives, both depending on the referent. First of all, as discussed above, the retention of the possibilities to exploit nuclear technologies substantially advances the idea of energy independence in Romania, given the possibility of a complete circuit from generating fissile fuel to use, by using national resources existing infrastructure. Energy security, therefore, derives from the country's fundamental strategic objectives. Defined, in short, by ,a country's ability to ensure its energy needs continuously and at affordable prices, energy security is a major concern in South-Eastern Europe" when looking at the map of energy relations in the region. Romania will, of course, want to maintain its status as a small energy importer ${ }^{466}$, for several reasons, one being this distribution of geopolitical relations caused by energy dependencies. "The natural endowment with varied energy resources and the industrial tradition in multiple branches of the energy sector is reflected in a diversified and balanced energy mix" ${ }^{467}$. Nuclear exploitation is therefore based on this line of Romania's independence and energy security in the next period.

Viewed in a top-down manner, or rather, from outside the sector itself, nuclear energy brings a considerable plus to increasing Romania's energy security. The benefits of operating nuclear technologies become apparent quite quickly when looking at the figures for electricity production in the national total (18\% at present, with $1400 \mathrm{MW}$ of combined installed capacity for the two units).

\footnotetext{
${ }^{464}$ US Department of Energy, U.S. and Romania Announce Initial Agreement on Cooperation for the Cernavoda Nuclear Power Projects and Civil Nuclear Power Sector in Romania.

465 Strategia energetică a României 2016-2030, cu perspectiva anului 2050, p.33.

${ }^{466}$ Eurostat. Energy dependency rate (\%). Romania still maintains a country profile with minimal dependence on energy imports, with approximately $22 \%$ of energy needs being from abroad in 2018 , one of the lowest percentages, well below the EU27 average.

${ }^{467}$ Ibidem.
} 
Equally complex is the issue of the security of the nuclear sector itself; in other words, when the issue of security is viewed from the bottom up, or from within the sector itself. The presence of a nuclear power plant in the state, as well as the related infrastructure for fuel generation (mines, nuclear fuel plant, warehouses, etc.), as well as for the safe use of the units, brings with it distinct challenges. The security of this whole area becomes an existential issue. We must not forget the major disasters caused by various deficiencies or errors in operation at nuclear power plants over time and the destructive capacity of these units, especially due to ionizing radiation ${ }^{468}$. Moreover, given the destructive potential of radioactive materials, in terms of the development of nuclear weapons, a matter of great concern is their safety.

The Kozloduy Nuclear Power Plant (NPP), Bulgaria also has 2 WWER1000 reactors (No. 5 and No. 6, put into operation in 1987 and 1991) with a total capacity of 2,000 MW, out of a total of 6. Reactors numbered 1-4 were shut down during 2002-2006. Luminiţa Simoiu states that NPP Kozloduy operates illegally in violation of international conventions, reactors 5 and 6 have been shut down seven times in the last 18 months, due to "serious technical deficiencies", as a SALTO (Safe Long-Term Operation) technical commission found. To the danger generated by the Kozloduy Power Plant is added the one produced by the construction of a landfill of 350,000 tons of radioactive waste in Radiana, Bulgaria, in the perimeter of Kozloduy, on the border with Romania, a warehouse that obtained a favorable opinion from the Dolj Environment Agency. ${ }^{469}$

On January 24, 2018, Austria warned that it intends to sue the European Commission (EC) for permission granted to Hungary to expand its Paks nuclear power plant. Austrian Minister for Sustainability, Agriculture and Tourism Elisabeth Koestinger wrote in a Twitter message that Austria will take action against the use of nuclear power plants and that there are sufficient reasons to sue Paks II.

The anti-Kozloduy civic platform - constituted by the Action for the Renaissance of Craiova (ARC), the Civic Association for Life (AcpV), the ProDemocracy Club Craiova Association, and the CRONO Association - proposes similar approaches, at the Romanian level, with those initiated by Austria in the fight against dangers represented by nuclear energy. The project to build the mega deposit of low and medium radioactive waste dates from 2011. By 2075, up to 345,500 tons of such waste will be stored near the Kozloduy plant. ${ }^{470}$

In 2013, the Austrian Environment Agency prepared a report on the Environmental Impact Assessment (EIA) prepared by the Bulgarian Ministry. It examined whether the EIA Report allows serious conclusions to be drawn about

\footnotetext{
${ }^{468}$ Chernobyl - April 26, 1986, Fukushima Daiichi - March 11, 2011.

${ }^{469}$ Interview with Luminița Simoiu, https://www.agerpres.ro/politica/2021/02/05/simoiu-partidul-verde-frecventacu-care-se-opresc-reactoarele-de-la-kozloduy-alarmanta-trebuie-eliminat-acest-pericol--656160.

470 Pericol nuclear la granita României, https://www.digi24.ro/stiri/actualitate/pericolul-nuclear-de-granitaromaniei-cu-bulgaria-subiectul-controversat-al-centralei-kozlodui-readus-in-discutie-la-craiova-880938.
} 
a potential cross-border impact on Austria. The report considers well-founded the Bulgarian conclusion that the Kozloduy Nuclear Power Plant is flood-protected and that the seismic risk is low (but points out that it is necessary to renew the seismic risk study since it was done 20 years ago). At the same time, they highlighted some unfounded conclusions and mistakes of the Bulgarian EIA report, including:

- shortcomings in reactor safety analyses, including neglect of the lessons, learned from the Fukushima accident and the use of the concept of practical disposal ${ }^{471}$;

- serious gaps in the assessment of the impact of external events caused by man, for example, accidents, leaks ${ }^{472}$;

- contrary to the provisions of the International Atomic Energy Agency, the EIA report does not contain considerations on the formation of shock waves and their potential impact on the buildings of nuclear units in the event of explosions outside the perimeter of the plant ${ }^{473}$;

- there is no intelligible technical basis for assessing accidents caused by design errors ${ }^{474}$;

- only three typical sets (scenarios) of weather conditions were used to assess the cross-border impact on Austria, without addressing the possibility of extreme weather conditions ${ }^{475}$.

Romania has assumed the responsibilities arising from the use of nuclear technologies with the civil application, both by forming an institutional apparatus to regulate the activity, but especially by transparent participation in various international bodies with responsibilities in the field, especially within the IAEA - International Agency for Atomic Energy, since its establishment in $1957^{476}$. At the national level, the National Commission for the Control of Nuclear Activities aims to comply with the measures contained in the National Strategy for Nuclear Safety and Security, the main programmatic document whose aim is to ,achieve the general framework nuclear" ${ }^{\prime 77}$. The comprehensive approach to nuclear safety aims to reduce the risk of manifestation or exploitation of several specific vulnerabilities and threats, namely the risks of accidental exposure to ionizing radiation of the population, environmental contamination, damage to nuclear or radiological installations, such as due to internal or external events, accidental or intentional, of illicit use of nuclear or radioactive materials, including the risk of

\footnotetext{
${ }^{471}$ Andrea Waller, Helmut Hirsch, Adhipati Y. Indradinigrat, Oda Becker, Matthias Brenner, Expert Statement to the Environmental Impact Assesment Report, Wien 2013, pp.60-61.

${ }^{472}$ Ibidem, pp.72-73.

${ }^{473}$ Ibidem, p.73.

${ }^{474}$ Ibidem, p.84.

475 Ibidem, p. 20.

${ }^{476}$ International Atomic Energy Agency (IAEA). List of Member States.

477 Comisia Națională pentru Controlul Activităților Nucleare (CNCAN), Strategia națională de securitate și siguranță nucleară, 23 July 2014, http://www.cncan.ro/assets/Informatii-Publice/Strategii-PlanuriPrograme/Strategia-de-securitate-nucleara/HG-Strategie-2014.pdf, p.1.
} 
proliferation of nuclear weapons and other improvised nuclear devices or radiological dispersal devices ${ }^{478}$.

Romania adopted a series of measures to prevent these risks, a series of prophylactic measures, aimed at drastically controlling the entire circuit of production, use, and storage of radioactive materials, preparation and planning of the response to nuclear and radiological emergencies, protection of insolation, and equipment, in particular in the light of its classification as critical infrastructure and the application of measures accordingly, the alignment of national legislation with that of international law, and its ongoing review, for relevance. Last but not least, the signing of the initial agreement with the USA on the expansion of the energy production capacity at CEN Cernavoda and the cancellation of the previous agreement with China is part of this line of securing the Romanian critical nuclear infrastructure.

\section{PERSPECTIVES - INSTEAD OF CONCLUSIONS}

Speaking about the development of the nuclear energy sector in the coming period, the focus of the discussion is on the future, which is why a current perspective takes the place of a conclusion, more than relevant. Considering that ,(1) the energy sector has a high capital intensity, [...] a long investment cycle so that a large part of investment decisions [...] will continue to take effect in 2050; and (2) EU energy and environmental policies [...] are built around the goal [...] of achieving a "zero-zero" emission level by 2050 " 479 , Romania's energy identity will continue to it also has a strong nuclear energy sector, estimated for 2030 at over a quarter of domestic electricity production. Moreover, technological developments, the tendency to adopt electricity transmission on a large scale, and the increase in electricity demand, coupled with the two requirements listed above, produce a cascading effect on how Romania's energy infrastructure will develop. It can be said, without much debate, that the nuclear sector will develop in the coming years, and the issue of its security will continue to be an open topic on the decision-making table.

At the same time, the same uncertainty that now affects the geopolitical space of Eastern and South-Eastern Europe, regarding the power relations established through energy dependencies, will most likely remain fundamental for drawing up energy policies in the region. Romania is in a favorable situation not only to get rid of such obligations, moreover but also to become itself an island of energy stability through the potential export of energy, implying a judicious development of this field. A greater contribution to the production of electricity through nuclear technologies can only be auspicious.

\footnotetext{
${ }^{478}$ Ibidem, p.2-3.

${ }^{479}$ Strategia energetică a României 2016-2030, cu perspectiva anului 2050, p. 64.
} 


\section{BIBLIOGRAPHY}

- Comisia Naţională pentru Controlul Activităţilor Nucleare (CNCAN), Strategia națională de securitate și siguranță nucleară, 23 July 2014, http://www.cncan.ro/assets/Informatii-Publice/Strategii-Planuri-

Programe/Strategia-de-securitate-nucleara/HG-Strategie-2014.pdf.

- European Comission. Planul Național Integrat în domeniul Energiei și Schimbărilor Climatice 2021-2030, April 2020, https://ec.europa.eu/ energy/sites/ener/files/documents/ro_final_necp_main_ro.pdf.

- International Atomic Energy Agency (IAEA), List of Member States, https://www.iaea.org/about/governance/list-of-member-states.

- Ministerul Economiei, Energiei și Mediului de Afaceri, Strategia energetică a României 2020-2030, cu perspectiva anului 2050 (proiect), http://www.mmediu.ro/app/webroot/uploads/files/Strategia\%20Energetica\% 20a\%20Romaniei_aug\%202020.pdf.

- Ministerul Energiei, Strategia energetică a României 2016-2030, cu perspectiva anului 2050, 19 December 2016, http://energie.gov.ro/wpcontent/uploads/2016/12/Strategia-Energetica-a-Romaniei-20162030_FINAL_19-decembrie-2.pdf.

- Nuclearelectrica. Homepage, https://www.nuclearelectrica.ro/.

- Transelectrica. Cerințe privind transparența informațiilor referitoare la producție. https://www.transelectrica.ro/ro/web/tel/productie.

- US Department of Energy, U.S. and Romania Announce Initial Agreement on Cooperation for the Cernavoda Nuclear Power Projects and Civil Nuclear Power Sector in Romania, 9 October 2020. https://www.energy.gov/ articles/us-and-romania-announce-initial-agreement-cooperation-cernavodanuclear-power-projects-and.

- US Department of State, U.S. and Romania Sign Nuclear Cooperation Memorandum of Understanding, 25 September 2019, https://www.state.gov/ u-s-and-romania-sign-nuclear-cooperation-memorandum-of-understanding/;

- Waller A., Hirsch H., Indradinigrat A.I., Becker O., Brenner M., Expert Statement to the Environmental Impact Assesment Report, Wien 2013, https://web.archive.org/web/20140227170407/http://www.umweltbundesamt .at/fileadmin/site/umweltthemen/umweltpolitische/ESPOOverfahren/UVP_k ozloduy7/REP0449_Kozloduy7_FSN_Kern_final.pdf. 


\section{Appendix 1}

\begin{tabular}{|l|r|r|r|r|r|}
\hline \multicolumn{6}{|c|}{ The situation of the installed capacity at SEN level from 01.05.2021 } \\
\hline Fuel & Groups & $\begin{array}{c}\text { Pi ANRE } \\
\text { license } \\
\text { (MW) }\end{array}$ & $\begin{array}{c}\text { Net P } \\
\text { (MW) }\end{array}$ & $\begin{array}{c}\text { Pr } \\
\text { (MW) }\end{array}$ & $\begin{array}{c}\text { Ap } \\
\text { (MW) }\end{array}$ \\
\hline Coal & 26,00 & $4.787,20$ & $3.469,30$ & 982,00 & $3.831,00$ \\
\hline Hydrocarbs & 139,00 & $2.839,99$ & $2.191,04$ & 484,41 & $2.370,04$ \\
\hline Water & 881,00 & $6.642,89$ & $6.310,98$ & 270,24 & $6.379,88$ \\
\hline Nuclear & 2,00 & $1.413,00$ & $1.300,00$ & - & $1.413,00$ \\
\hline Aeolian & 114,00 & $3.012,91$ & $2.964,54$ & 24,63 & $2.995,68$ \\
\hline Biomass/Biogas/Others & 57,00 & 137,48 & 125,39 & 4,91 & 132,41 \\
\hline Solar & 629,00 & $1.392,96$ & $1.307,36$ & 71,70 & $1.326,49$ \\
\hline Geothermal & 1,00 & 0,05 & - & 0,05 & - \\
\hline Total & & $20.226,48$ & $17.668,62$ & $1.837,94$ & $18.448,49$ \\
\hline
\end{tabular}

\section{DEFINITIONS:}

Power installed from the ANRE license (Pi ANRE license) - the installed electric power indicated in the specific conditions associated with the ANRE license.

Net Power (Net P) - is the power that the generator can deliver to the network for marketing purposes and is equal to the gross available power minus: power consumed in own services (CSI), the share of consumption of general services (Csg), power losses in the transformer block (PTB).

Net $\mathrm{P}=$ GrossAP $-(\mathrm{Csi}+\mathrm{Csg}+\mathrm{PTB})$

Permanent reductions (Pr) - the difference between the installed power of the power plants and their available power, if this power reduction cannot be eliminated in a shorter term than 1 year. In the case of groups in conservation, the permanent reductions will be equal to the installed power.

Available Power (Ap) - the maximum gross active power, of duration, that a generating group can give, respecting the mechanical and electrical safety conditions. For operating groups, the calculation formula is: Gross $\mathrm{AP}=\mathrm{Pi}-\mathrm{Pr}$

Compared to 2019, the percentage of electricity from burning fossil fuels fell from $40 \%$ to below $38 \%$ in the first quarter of 2021. The level of electricity produced from hydropower rose almost 33\%, approaching the distance low percentage of energy from fossil fuels. Another significant increase was also registered by wind energy, which is approaching the threshold of $15 \%, 4 \%$ more than in 2019. An increase of $4 \%$ is also found in the case of energy from solar sources and biomass, these representing $7 \%$ of the total. According to the data provided on the TransElectrica website, the contribution of nuclear energy in the SEN system has decreased to 7\%, a loss of $12 \%$ when compared to 2019. Furthermore, most of the electricity produced nationally comes from little or no polluting sources, which are registering an increase of $2 \%$, compared to 2019 , concerning fossil fuel-produced energy. 